\title{
Writing as a Tool for Transformation
}

\author{
Jesse Stong, Concordia University/National Theatre School of Canada \\ jessestong@hotmail.com
}

\begin{abstract}
The author (Social Worker, Art Educator, Theatre Artist) discusses the creation and evolution of the Identity Writing workshop; a life writing exercise that helps students, artists, and teachers integrate their personal/political experiences of change into meaningful and authentic artistic expressions. Reflections stemming from the junctions between the author's personal and professional lives provide compelling insights into moments of transformation through art-making. A simple writing activity is included for new, emerging, or established artists and creative teachers.
\end{abstract}

Keywords: Writing; Theatre; Identity; Social Work; Narrative Research

\begin{abstract}
Introduction
T believe that all forms of art can be dynamic tools for social change and self-discovery. I have personally experienced lives changed forever by the integration of creative processes into everyday living. It is my deep passion and utmost respect for these artistic experiences of selfexpression that have led me to spend my days (and often late nights) creating theatre while also supporting first-time, emerging, and experienced artists of all fields to integrate innovative writing and performance activities into their practice. In the following narrative, I will deconstruct my story of becoming a writer, investigating the links between artistic creation and my everyday experience. My story is a narrative of transformation with and through literary art practice. As a writer I will explore my own history: my story working in theatre institutions, public and private schools, social services, and community groups. I will share how I utilized the discipline of writing as a tool to engage people from all walks of life in becoming invested storytellers. I will conclude this article with a writing activity designed to support all types of artists (even those who do not recognize their inherent ability to make, share, and play).
\end{abstract}

\section{Theory}

Like so many passionate artists across mediums, my interest in life writing theory and narrative-based art education emerged out of a deep personal need; growing up there was a serious lack of creative writing and meaningful art-making experiences in my education, and I had never fully understood what art-education pioneer Greene defined as "the significance of encounters with the arts for classrooms in which the young are moved to imagine, to extend, and to renew" (1995, p. 132). It was much later through the discovery of my own interest and ability in creative writing that I at last experienced how artful expression was indeed a way of learning human "freedom, hope, discovery, and light" (Greene, 1995, p. 133). Through building stories based on the chapters of my own life while also creating fiction inspired by my overly active imagination, I tapped into what Snowber (2005) describes as a "certain kind of rigor, which asks the individual to look at all aspects of personal growth, including light, dark and shadow" and discovered it was true that "the soul needs a certain acceptance to come out and play, to come out and work" (p. 351). 
In 2009, four prominent life writing scholars, Hasebe-Ludt, Chambers, Chambers, \& Leggo, came together to create the article "Life Writing and Literary Métissage as an Ethos for Our Times". This extensive exploration of the theory, history, and political powers of narrativebased art-making reveals how the practice of life writing remains a relatively new and only recently academically-validated form of research and creation. The authors bring readers through the evolution and adoption of life writing by the social sciences; an important point in our modern history when life writing gained legitimacy as a practice, and show how this cross-discipline collaboration allowed the narrative-based trend to continue rising across other disciplines: life writing began to be used to analyze phenomenon (phenomenology), to look at group structures (socio and ethnography), and to analyze the individual (psychiatry and psychotherapy). The article also provides research to highlight how life writing can be attributed to several political and academic successes: the emergence of Women's Studies in academia, emerging largely in part to the studying of life writing from women; the sharing of stories about being constrained by gender, suffocating the self by societal roles, and feeling trapped in the prison of the home were central components to the emergence of feminist literature studies. Also, the evolution in narrativebased writing that expanded into the 1980's: the protest of post-structural queer, race, and feminist life writing being adopted by social sciences across the globe. Life writing at last reaches a pinnacle in our current time, where the World Wide Web has made shared lives truly "an ethos of our time" (p.

$18)$.

Rather than avoiding, denying, or criticizing this rising trend of sharing our lives, the theoretical underpinnings that inform the work I do arise from questioning how we can utilize life writing as a form of art education in order to dramatically enhance identity formation, selfempowerment, political discussions, and social interactions. Sinner (2013) states, "storying the past can function like a social process, where relational qualities (dialogical and interactive) of the past and present are in movement" (p. 246). It is this movement, this transformation, I encourage participants of my workshops and artistic projects to engage with. With increasingly difficult political and personal issues being brought to our global attention at a constant rate, I believe life writing as a practice is becoming more relevant and needed than ever. As Greene (1995) warned, we continue to live in a "world of fearful moral uncertainty - a world where it appears that almost nothing can be done to reduce suffering" (p. 122) and, like Greene, I believe something can be done, that things can change, and that change must come creatively from within.

Life writing and narrative-based research, especially when fostered and developed within marginalized populations existing outside of the master narratives, can become some of the best weapons we have against discrimination and oppression. "Counter-narratives are tellings of the world that synthesize notions of truth from multiple historical, sociological, and personal, anecdotal, familial sources" (Acuff, 2013, p. 223). These counter-narratives work to bring fresh perspectives and unheard stories into the dialogue of our current society; life writing illuminates our subjective understandings of the past. As Diana Korzenick (1984) reminds us, it is important that art teachers no longer "consider historical research an arcane, mysterious, or dry pursuit. History explains where we are and is grounded in everyday life" (p. 128). Through looking at history using an examination of multiple life stories, we develop a stronger understanding of the theory that "within the personal stories, there is also an institutional story" (Sinner, 2013, p. 248) and recognize through the ways we ourselves and others tell our individual stories that "facts are fluid and may be interpreted differently from diverse perspectives" (Sinner, 2013, p. 242).

As Pinar (2012) theorizes, life writing "represents an economy of the self, wherein the narration of one's story functions to preserve oneself" (p. 49). Life writing is not simply the act of 
keeping a diary, but rather the dynamic use of narrative-based tools to create and share writing directly from one's personal experiences: "the architectural rebuilding of a self, with materials previously excluded, now excavated" (p. 49).

\section{Methodology}

Using innovative free-writing activities I have designed curriculums to "shake preconceived ways of thinking and perceiving, which invite students to a fresh listening to their lives" (Snowber, 2005, p. 347). In the many classrooms I visit, I always insist that the participants sit in a circle and share their creative offerings within that circle; we build artful expressions as a team and we learn to appreciate the diversity of work while offering critical feedback. Whether participants are first-time life writers or writers who possess a long history of creating work from their personal narratives, I hold them to the same standards that I hold myself to as a professional writer, and work tirelessly to value and serve their developing stories. Like Mason (2002) describes, "the artist must learn to serve the work, to hear where it is going and respect that it has a life of its own. Not unlike listening and walking alongside students in the mentoring process, we must listen for the cues, linking them to their passions and callings" (p. 346).

Central to all the artistic experiences I facilitate is the authentic exploration of personal moments of change: capturing these moments on the page, working to document the evocative elements of these memories for story material, and creating powerful writing inspired by these transformative chapters of our lives. Exploring moments of change has been at the thematic heart of my praxis for over ten years. I believe that the success of a story depends on incorporating some form of change. If nothing changes, nothing happens. As audiences, we want to see characters go on a compelling journey; we want to see them challenged and transformed, victorious or defeated. As artists we want to learn from and be moved by the work we create; we want to dive deeper into ourselves and come out not simply with a product to share, but also with a transformational experience to carry forward. As a facilitator of art education and theatre, I actively seek to find the unheard stories: the gaps and missing pieces, or the qualitative details that can paint a deeper picture of our humanity. I create activities that foster the opportunity to experiment with writing, whether it be academic or creative, and recognize that it is a powerful tool to change ourselves, change the narrative, and ultimately try to change the world.

Another way of phrasing my methodology is to say, as Irwin (2003) articulates, that I am supporting people to look for moments of insights that "delve into the inner structures of things, beings, and ideas. Insights [that] perceive and apprehend self-knowledge" (p. 64). This fascination with self-knowledge and the openings that self-discovery can create is why I believe I am a dedicated facilitator, not because of my set of skills so much as my willingness to take "the journey of mentoring" as a means of exploring "the poetry of life" (Snowber, 2005, p. 352). Similar to what Snowber suggests, I facilitate with the belief that teachers must make "connections between the art of mentoring and the art of listening in the creative process...central to this process is the notion of deep listening to our self and each other, and form, which is being created. As human beings, our lives are art-works, ones in an ever-changing mode of being and becoming" (2005, p. 352).

In my own creations and while working with life writers from many different backgrounds, I have consistently developed and evolved my ability to actively listen; a method of facilitation that Mason (2002) calls "the mark of an expert" as they manage to "make things look easy, because they have a refined sensitivity to professional situations and a rich collection of responses on which to draw" (p. 16). I encourage each person I support to not only dive deeply into their own stories, 
but also understand the universality of their life experiences, as life writing is as much about selfexploration as it is about "being critical or emancipatory.... concerned with wider ethical, social and political issues, including crucially the institutional and societal forces which may constrain the individual's freedom of action or limit the efficacy of those actions" (Mason, 2002, p. 17).

My method is process over product, pushing participants to stop editing and start building an arsenal of images, ideas, emotions, and characters from their authentic experiences. In my emerging practice as a young writer, I started to realize through trial and error that by becoming clear on my emotional expertise, what I knew well and had personally experienced, I could create characters that were rich and authentic; I could build stories that resonated deeply; I could find images that showed what I was trying to express without flatly telling. As Rita Irwin articulates, I am now an advocate for noticing and searching for ways to engage with the art living, surrounding, and within us:

What would we notice if we allowed ourselves to stop and attend to the aesthetic qualities in our lives, work, surroundings and relationships? How might our interactions with others change if we contemplated the aesthetic qualities embedded within our collegial discussions, our lessons, or our decisions? How might we open ourselves up to appreciating the aesthetic qualities of experience before acting upon those we want to change? (Irwin, 2003, p. 74)

The artful act of noticing is the key ingredient to my method as an artist and life writing educator, as I push participants to generate writing about what exists around them while also recounting the transformational moments that shaped their lives, "The Discipline of Noticing provides a way of working against the tendency to forget, to not notice, to be so caught up in your own world that you fail to be sufficiently sensitive to possibilities" (Mason, 2002, p. 13). In the building and sharing of my free-writing activities, all of which encourage others to get messy on the page and allow ideas to come and go without censor, I have seen tremendous accomplishments. I have witnessed narrative-based art that is incredibly personal while still having an emotional impact with larger audiences, and have watched the elimination of writer-block through the allowing of open exploration and play. In my practice as an art educator, I use the creative writing process as a tool to explore, as Irwin (2003) herself questions, "how might our educational institutions look if curriculum leaders and teachers chose to be guided by aesthetic sensibility and attunement rather than comfortable routines, surrender rather than defensiveness, affirmative engagement rather than fault finding?" (p. 68).

\section{Personal Reflection: The best-worst change}

My journey as a writer began on December $30^{\text {th }} 2002$ when I was hit by a drunk driver. I was eighteen years old, on winter break during my last year of high school. Out of all eight people involved in the crash, I was the only one with serious injuries: a fractured skull that required twenty-two staple stitches and many days of bedrest. I can remember little from that evening: the rock music on the radio moments before impact, the small car ahead of us swerving back and forth in the snow, the headlights that seemed to come so close that they moved right through me...but what I do remember clearly is this; at the moment of waking up in the ambulance, I had a deep and immediate sense that this traumatic event was in actuality the best thing that had ever happened to me. It was a change, a dramatic transformation, and one that would become the inciting incident to my entire practice as a playwright, director, and art educator.

After my car crash, while recovering and lying for hours in a hospital bed, two things started to run through my recently opened mind: one was that I desperately needed to create art, 
and the other was that I needed to come out of the closet, admitting to myself and others that I was gay. To fill the long gaps between visitors, I began to write for the first time in my life, at first journal reflections and then later poetry and creative fiction. Though I was only putting pen to paper, these simple artful expressions created a revolutionary movement in my life. My writing allowed me to confront a difficult time in my past. Before the accident I suffered from depression, I had actively been hiding my true sexuality, and many elements of my authentic identity had been suffocated and completely unexplored. After the crash, my writing led me to remember my past affinity for theatre in high school... I had totally forgotten those morning classes on the dusty stage! Yet I also came to realize I had always participated in drama as an actor; I was eighteen years old and had never really created anything. Like a warm light turning on in cold and dark room, I began to learn through the practice of writing what Pinar (2012) labels as "the self as witness", and writing became a way for me to "preserve" myself and have an appreciation for experience; for my own experience, and for myself (p. 48-49).

I found myself writing with a strong sense of purpose; with a drive that came from the dual realization that life was short, and that I may have something significant to say. I had read so many great stories, and acted in many excellent plays, yet was never provided a structure for diving deep into my own creative writing practice. I was beginning to use my writing to not only reflect on my past, but also create authentic artful expressions that really captured the essence and emotion of what I had personally experienced (see Figure 1).

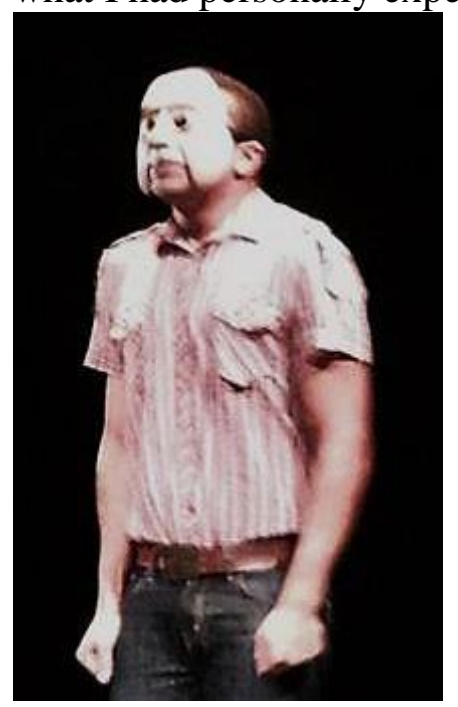

Figure 1. Actor Mike Payette in VCARDS. Centaur Theatre - Wildside Festival 2014. Image by Jesse Stong.

We are all big fakes.

Fake it until you make it, and that's what we all do and that's what the universe does...gives us what we want even though we're only pretending to be ready.

Takes me over, like natural urges.

Fake my way right into it, calm, straight in the eyes, brave.

Fake prepared. Fake like it's done, a million times, before and already and now...

No big deal. Nothing at all.

We both know we aren't supposed to, but we both feel it. 
Intensity, unspoken energy, and for a moment....we become fire.

This excerpt is from a monologue I created for the play VCARDS, a comedy/drama performed in 2014 at Centaur Theatre, where four actors used masks to portray twenty five different characters, all sharing personal reflections on experiences of virginity. The above monologue was performed at the very end of the play, an intimate last moment where a young gay male talks about his first sexual experience. The short piece was more than a little autobiographical, and was particularly difficult for me to write. It is always challenging for an artist to walk the line between fiction and biography, and I find every time I dive deeply into my own history and identity to create, especially when looking into the more difficult corners of my life, the result is not only a more genuine and authentic quality to the work, but also a dynamic change happens from within. Experiences like the production of this play helped me to understand the power of sharing my life narrative in artistic ways with others.

\section{Personal/Political Transformation}

A few months after my car crash, I graduated from high school and within three days of receiving my diploma, packed up everything I owned into three suitcases and moved to downtown Toronto in the hopes of becoming a bohemian urban artist. I also applied and was successfully accepted into the Social Work program at Ryerson University, because in my youthful ambition I wasn't only interested in writing but also in saving the entire world. The early 2000's were an amazing time to be a young gay man in Toronto. Gay marriage was illegal, a hot trending topic debated daily on the news, and the Toronto gay village was an exciting and political party that was only starting to be tainted by the apathetic yawn that would arise over the next generation. In all of my blind confidence, and after binge-watching Carrie Bradshaw unabashedly spill all her dirt in print on Sex and the City, I decided to submit some articles for the position of queer youth columnist at Fab Magazine (Canada's gay-scene magazine at the time) and was offered, much to my surprise, a bi-weekly column called TWINK about my experiences as a fresh gay boy in the city. Writing every other week to a national audience about coming out, bullying, about my high school lover, about body issues as well as other humorous and painstaking problems I faced as a queer youth, I started to experience what Pinar (2012) describes as "the architectural rebuilding of a self, with material previously excluded (now excavated), a self more spacious, more inviting, especially to others" (p. 49). In search and in awe of the marginalized narratives of others, I was at last introduced to mind-expanding experiences of queer art, history, and culture. For the first time in my life, I was mentally, physically, and spiritually home.

I went on to participate and later assist in the direction of the queer youth theatre program at Buddies in Bad Times Theatre while also in a placement as art facilitator with Sketch Art Studio for Street-Involved Youth. Working with young people, I began to comprehend the astounding power of the arts with its ability to cross boundaries and build relationships in ways that traditional social work and counselling never could. I also started to have a richer understanding of how art, and more specifically life writing, could be integrated into practice as a tool for both social justice and self-empowerment, especially during periods when "the public sector does not invite our identification, indeed, when it seems to require our cynicism, even bitterness" (Pinar, 2012, p. 47). The creation of my artistic practice evolved into personal, political, and socially-conscious statements that presented audiences with "counter-narratives and counter-stories concerning history" disrupting the master narratives by introducing "diverse perceptions of the world" (Acuff, 2013 , p. 221). With the transformational combination of my artistic practice, my engagement with 
queer theatre, and my education in social work, I was at the center of an entirely new world. My dark and closeted past felt a million years away.

Continuing my journey as an emerging writer, I found myself evolving into an artist with an intense interest in using theatre to rediscover the past, rediscover the self, and connect us to our own personal/political culture. Between the years 2006 to 2010, I focused my energy on producing theatre projects in which I utilized my experimental writing and performance workshops to support emerging artists to develop and perform their own theatre creations around socially conscious themes: "The Violence Project", "A Night of New Voice" (immigration stories), "Grow \& Shrink" (healthy body image), and "Protestival" (real Canadian protest stories) are just some of the many important themes I directed these artists in exploring and performing across several of Toronto stages (Passe Muraille, Theatre Centre, Cameron House, Buddies, Factory, YPT and several others). As a developing director/dramaturge, I began to understand the challenge and power of really listening to the lives of young artists, understanding that "within the personal stories, there is also an institutional story" (Sinner, 2013, p. 248). Through the process of creation I was finding new ways to use the stage as a dynamic space for sharing the emotions that were stirring inside of me, and examine issues close to my heart (see Figure 2).

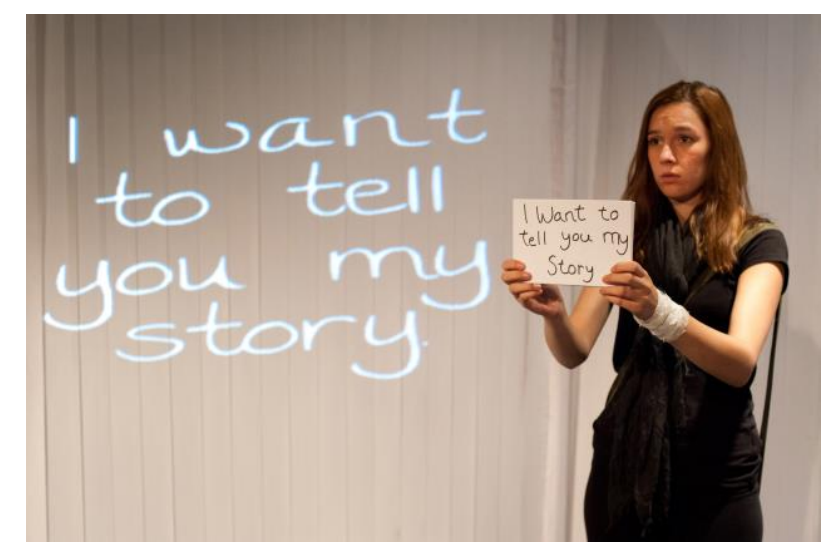

Figure 2. Actor Hayley Kezber in SHARED ACCOUNT. Geordie Productions 2015. Image by David Babcock.

AURORA sits at the computer. She types into Facebook Search: "I wish I was dead"

Hundreds of them. Thousands. Some are just kidding around; guys who wrote it because their team lost; girls who wrote it because they missed a concert... but a lot of them look really serious. Present thoughts: I know how they feel. Lost on the internet. Sitting behind a computer feeling totally alone with the entire world at your fingertips.....and I can't stand it. Somebody writing "I wish I was dead" and nobody hearing it. Nobody doing anything. (AURORA types) "There's a door between two rooms. One room is light and the other is dark. When you open the door...the light always wins" ...Send

The above excerpt is a moment from one of my most successful and difficult to create plays, Shared Account, based on the bullying and unfortunate suicide of teenager Amanda Todd. Though I created a fictional young female character, the play was also a deep and difficult exploration of my own experiences with bullying and depression. Normally my writing process 
involves a long gestation period; I often construct my characters over many months and sometimes years, yet I was so disturbed by the viciousness of this story that my first draft was completed in a manic eight hours of writing. The play was produced in 2013 by Geordie Productions, and went on to a 100-school tour across Quebec. Shared Account continues to be my greatest achievement as a playwright, not only for capturing the interest of so many young audience members on the amazing tour, but also for capturing so much of my own raw emotions. I was forced to dig deep in order to put myself, my own identity, into the characters I create.

\section{Identity Writing}

After having several experiences of utilizing my own history and identity to create dynamic pieces of theatre, and creating systems to support young artists in doing the same, I began to develop a curriculum of innovative workshops to support other people from across all ages and abilities to break through writer-block, connect deeper to their own histories and narratives, and have the powerful experience of sharing their authentic offerings with others.

Recently, I have become a registered facilitator with the Quebec Repertoire, offering my workshops to schools across the province. I have evolved my teaching praxis beyond creative writing alone, and now provide interdisciplinary artistic tools, tapping into movement, performance, visual art, and puppetry activities to inspire the writing, while also using writing to deepen and expand other forms of artistic pursuit. The principles of transformation and personal investment are the same, and I continue to support people of all ages and abilities, as well as variety of teachers, to create and share artful expressions that are based on real lived experiences and authentic emotions. Whether I am offering a workshop on bringing puppets to life for children (see Figure 3), or teaching thesis writing with university students, my guiding principle of investigating the authentic self is always present. Whenever one is creating, and for whatever purpose, the most important goal is to "see more in our experience, to hear more on normally unheard frequencies, to become conscious of what daily routines have obscured, what habit and convention has suppressed" (Greene, 1995, p. 123).

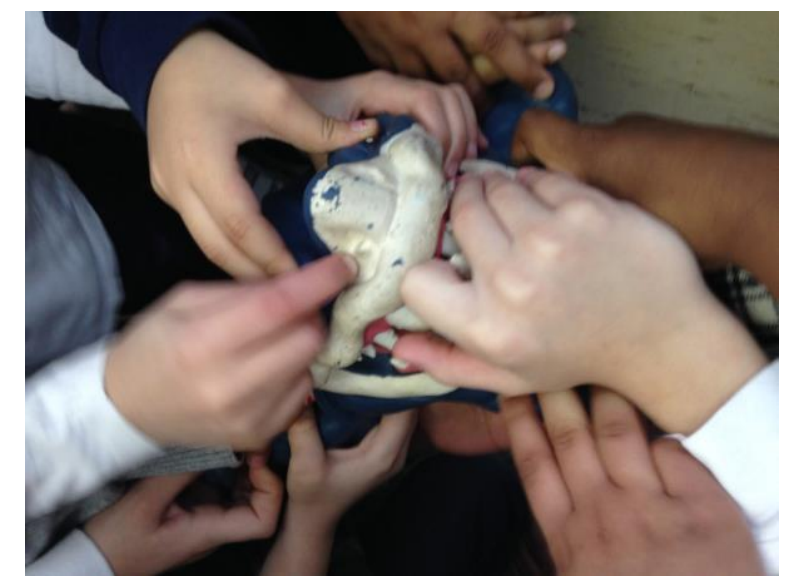

Figure 3. Coping Skills through Puppetry Workshop. 2015. Image by Jesse Stong.

In my original Identity Writing workshop, which still remains my most popular public offering, I begin by asking participants to write down three times in their lives when, in the flash of a moment, everything changed. I start by telling them that nobody is going to know what they are writing about; we are going to use this exercise to create fictional characters and story ideas, 
but the original memory they explore will not be shared with the group. They are encouraged to be as personal and uncensored as they like. I give them one minute to think of three moments, and offer a few cues to support the process: That time you lost something or someone? That time you started something new? If someone was writing a book about you, what would be the main chapters be? I then ask them to select one of the three memories, the one they feel the most emotionally invested in, and ask them to relive that moment on the page, not as a crafted piece but as a freewriting exercise. I tell them I am setting a five minute timer, and everyone will be writing for five minutes non-stop. Before they begin I make sure they understand the strict rules of the activity: the first is that nobody will read this, so they can be as messy and personal as they like. The second rule is they must write in first person and present-tense as though the moment is happening again right now. A third rule is they have to write whatever comes to their mind related to that memory, even if it doesn't seem directly related, even if it isn't in chronological order and even if it means interrupting one sentence for another. This is not a story. They should not edit, they should just write the words down as they come. The most important rule of all is that they have to continue to write the entire five minutes without rereading, erasing, editing, or stopping to look up at the sky. I tell them (though I have never actually done it) that if I see the pencil stop moving I will rip up their paper and make them start their five minutes over again. The goal, whether you tell them or not, is transformation: a change in writing habits (integrating free-association into your art), a change in artistic mindset (integrating a deeper value of process over product), and often a change from within (integrating a more reflective practice, sharing with a creative force).

The element of surprise is essential to this activity, and that surprise depends on the pencil continuously moving (see Figures 4 and 5). A second before they begin, I tell the participants the most helpful trick of all; if they feel blocked they should literally write "bla bla bla" until the next word comes. What I am essentially asking them to do is to stop creating a product; stop searching for a finished story, and allow for the authentic act of noticing. As Mason (2002) describes, noticing "seems a simple notion, and rather obvious. But in fact it is much more complex and far reaching than first appears" (2002, p. 29). 


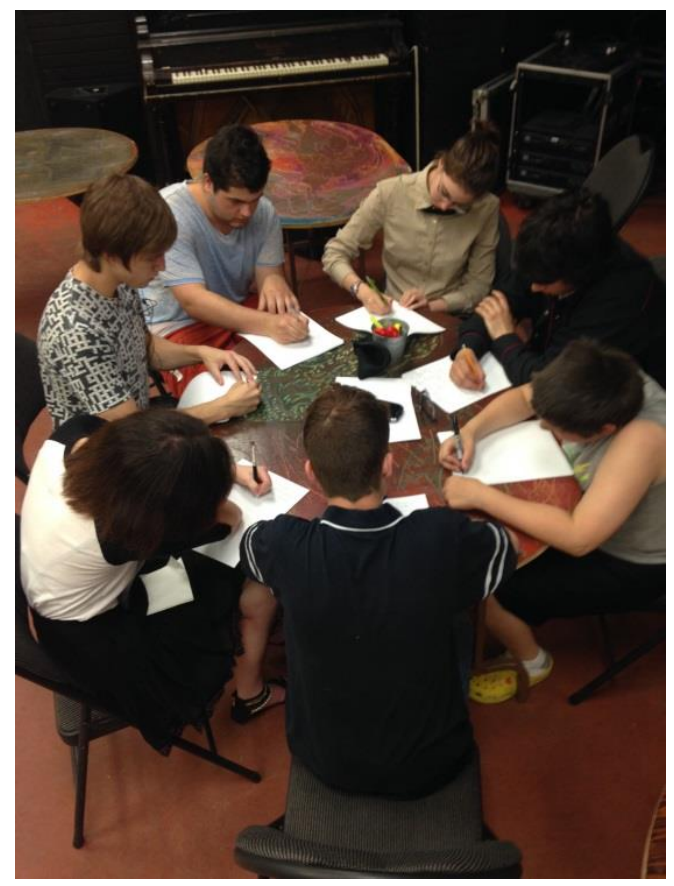

Figure 4. Identity Writing Workshop with Youth. ICI PAR LES ARTS 2016. Image by Jesse Stong.

After the free-write, and while the moment of change is still fresh in their minds, I ask them write down on a blank part of the page the following: I was...I learned ...I am ... and challenge them to answer these power statements with emotionally evocative words.

In that moment of change that they just explored, a transformation in character occurred. If that wasn't true they wouldn't remember it, and they wouldn't affiliate it with the concept of change. They were something before that moment happened, they learned something in that moment, and they are something different because of it. At this point, I use my car accident as an example to better illustrate what I am asking of them; I tell them that I would not say "I was 18 years old driving on the highway, I learned drunk drivers can't drive..." as that is telling and not showing. I explain that the "I" statements should be used in a more universal way, for example, "I was living in fast motion. I learned life is short. I am more present." Because we are going to share these power statements, it is important that they understand there should be no specific details in the chosen words, only emotions. Participants are given one minute (or two if needed) to try to answer their own power statements, and then are asked to share their responses to the class if they feel comfortable. In the hundreds of times I have done this activity, this is almost always an exceptional moment of group sharing and team building, as well as a powerful opportunity for those brave enough to contribute. As I listen to their statements, I look for in-between spaces, contradictions, statements that really stand out and evoke strong feelings in the room. I encourage all statements; there is no wrong answer here, even confusing statements, and statements that cause unexpected reactions from others, statements that seem complicated and unclear. I tell them to think about what these statements say about their potential style as a writer; is there a theme of family? Self-empowerment? Romance? Are the statements dark and psychological, or light and humorous? Most of all I listen for what surprises me in the answer, as that is the best hint towards an area the participant should continue to explore through creation. 
Though some do not share their "I" statements, many choose to articulate what they felt during the free-writing and the statement creation. What makes the exercise interesting from an art education perspective is that none of the participants speak specifically of what they wrote about during the timed free-write, yet they are able to articulate powerful and emotional statements that evoke universal thematic connections with the listeners. I support the students by encouraging them to see that their power statements are but some of the many examples they have within them that make them emotional experts. I then help to facilitate a writing environment where students create fictional stories and characters based on one of their power statements. The results are consistently above and beyond expectation. By first connecting artists to their own emotional expertise, exploring in depth the real changes that occurred in their life, they are able to create stories and characters from a powerful place within. Students are challenged to use their own identity to transform their creative writing.

\section{Conclusion}

I work tirelessly in my artistic creations, my life writing research, and my teaching to gain knowledge and experiment with new ways of practicing and being. I believe a true artist and an exceptional facilitator "cannot be 'fixed'; they have to engage in some personal change for themselves, and hence they can be thought of as students" (Mason, 2002, p. 16). What keeps me producing and teaching while continuing my studies in and out of educational programs, while at times trying to pay the bills, and while often lacking sleep and sometimes sunlight, is the fact that I personally know how art can save lives. Art has allowed me to become the person that I am today, and provided me with a platform to express myself, appreciate myself, and authentically change myself. The ultimate goal of my pedagogical process is to share with others the tools for change that I have come to understand for myself; this is the knowledge that I have had the privilege of learning and understanding through the actions of countless other passionate creators, researchers, and art educators.

\section{References}

Acuff, J. B. (2013). Discursive underground: Re-transcribing the history of art education using critical multicultural education. Visual Inquiry: Learning \& Teaching Art, 2(3), 219-231.

Connelly, F., \& Clandinin, J. (1988). The idea of curriculum. In Teachers as curriculum planners: Narratives of experience (pp. 3-10). New York: Teachers College Press.

Fassett, D. \& Morella, D. (2008). Remaking (the) discipline: Marking the performative accomplishment (dis)ability. Text \& Performance Quarterly, 28, 139-156.

Glesne, C. (1997). That rare feeling: Re-presenting research through poetic transcription. Qualitative Inquiry, 3(2), 202-221.

Greene, M. (1995). Art and imagination. In Releasing the imagination: Essays on education, the arts and social change (pp. 122-133). San Francisco: Jossey-Bass.

Hasebe-Ludt, E., Chambers, C., Chambers, C. M., \& Leggo, C. D. (2009). Life writing and literary métissage as an ethos for our times. New York: Peter Lang Publishing, Inc. 
Irwin, R. L. (2003). Toward an aesthetic unfolding: In/sights through curriculum. Journal of the Canadian Association for Curriculum Studies, 1(2), 63-78.

Korzenick, D. (1984). Doing historical research. Studies in Art Education, 26(2), 125-128.

Mason, J. (2002). What is research? In Researching your own practice: The discipline of noticing (pp. 1-30). New York: Routledge.

O’Donoghue, D. (2011). Classrooms as installations: A conceptual framework for analysing classroom photographs from the past. History of Education, 39(3), 401-415.

Pinar, W. (2012). From autobiography to allegory. In What is curriculum theory? (pp. 43-66). New York: Routledge.

Sinner, A. (2013). Archival research as living inquiry: An alternate approach for research in the histories of teacher education. International Journal of Research \& Method in Education, $36(4), 241-251$.

Snowber, C. (2005). The mentor as artist: A poetic exploration of listening, creating and mentoring. Mentoring and Tutoring, 12(3), 345-353.

Soucy, D. (2013/1985). Present views on the past: Bases for the understanding of art education historiography. Canadian Review of Art Education, 40, 20-27. 